\title{
Eminence of the Mind over the Body
}

\author{
Belko Ouologueme1, Yacouba Coulibaly ${ }^{2 *}$ \\ ${ }^{1}$ Département de Philosophie, FSHSE de Bamako, Bamako, Mali \\ ${ }^{2}$ Département Psychologie-Pédagogie-Philosophie-Sociologie, ENSUP de Bamako, Bamako, Mali \\ Email: belko_wologueme@yahoo.fr, *bayacoulib@yahoo.fr
}

How to cite this paper: Ouologueme, B., \& Coulibaly, Y. (2019). Eminence of the Mind over the Body. Open Journal of Philosophy, 9, 281-294.

https://doi.org/10.4236/ojpp.2019.93019

Received: April 24, 2019

Accepted: July 19, 2019

Published: July 22, 2019

Copyright $\odot 2019$ by author(s) and Scientific Research Publishing Inc. This work is licensed under the Creative Commons Attribution International License (CC BY 4.0).

http://creativecommons.org/licenses/by/4.0/

Open Access

\begin{abstract}
The mind-body problem is far to be an old issue because it keeps rising new understanding and perception without ceasing. In the contemporary philosophy of mind, the essence of the question should not be any more whether there is a distinction between mind and body. Rather philosophers should be more focused on the interaction between mind and body. The new interest is how does it happen? This article argues the eminence of the mind over the body. Mind-body interaction is not equal. It is rather the relation of dominion in which the mind masters the body. When the contrary happens, we call that misleading. In that case, the man becomes a slave of passion going here and there without focus. Whenever the mind remains in control, man reaches certainly to the goal.
\end{abstract}

\section{Keywords}

Eminence, Mind, Over, Body

\section{Introduction}

In the field of philosophy, the interaction between body and mind is not a new thought. From the earlier philosophers to the contemporary thinkers, the mind-body problem keeps coming over and over.

In this work, we will show the eminence of the mind over the body. We will also argue that human being is more determined by the mind than the body. That shows that the mind governs over the body. The decision of the action comes before the action itself. Why do people do what they do? Why do they refuse to be involved in some actions? The answer is simple: the ideology that a man receive from his childhood, believes, education determine his action. The confident that we develop in our mind leads us to take footsteps into action. That's why Descartes could say in meditation II: "But what then I am? A thing 
which thinks. What is a thing which thinks? It is a thing which doubts, understands, conceives, affirms, denies, wills, refuses, which also imagine and feels". ${ }^{1}$

In this analysis, we will acknowledge that the mind does not also completely escape from the influence of the body even if those influences are minor accordingly. For a best achievement to our goal, we will first of all have a brief presentation of dualism (mind-body distinction) through some authors; then develop the eminence of mind over the body in different fields such as philosophy, medicine, psychology, Christianity and personal perspectives.

\section{The Mind-Body Distinction (Dualism)}

Dualism is a set of view about the relationship between mind and body. The main idea is that the soul and body are two different substances and are separated with no substantial and natural connection. It begins with the claim that mental phenomena are in some respects, non-physical. Samkhya and yoga schools (650 BCE) of Hindu philosophy is one of the earliest known formulations of mind-body dualism. We will consider some philosophical argumentations such as Plato's, Aristotle's and Descartes' view of dualism.

\subsection{Plato's View of Dualism}

The earliest discussion in western philosophy started with the writings of Plato. Dualism as it was introduced by Plato is a theory that there are two kinds of substances: physical substance and mental substance. Physical substance means something that is material which represent our body. The mental or immaterial substance, in human being, is called self or soul (Crivellato \& Ribatti, 2007). Plato was convinced that humans' Mind or Soul could not be identified with physical body (Bostock, 1986). Plato came to the conclusion that the body or matter is incomplete and the mind is perfect. The mind represent the soul which governs its motions in the heavens. The evils and imperfections of the physical world are therefore attributed to the body or matter (subject to constant change and transformation).The soul contains the reasoning element within man, and is the part of man which survives death. Plato is convinced that soul in itself is good, perfect and full of goodness, and eternal. The importance of this was not purely eschatological but had relevance for this present earthly life. "The soul has come into the sensible world, and it must return to the supersensible world at the death". ${ }^{2}$ If not the soul will be diverted from its true destiny (Plato \& Grube, 2002).

Therefore, the body, being made of matter, appeared as less than real. According to Plato the body is a prison house of the spirit, a detriment to perfection, a hindrance to wisdom and knowledge. The body is a source of endless trouble to man. He felt that man could not become pure until death, when the soul will be departed from the body and exist in herself alone. Then, having got ${ }^{1}$ Internet Encyclopedia of philosophy, 1996. This file is of the 1911 edition of the philosophical works of Descartes (Cambridge University Press), translated by Elizabeth S. Haldane. 9-10.

${ }^{2}$ The same idea is in Bible, Ecclesiastes 12:7. 
rid of the foolishness of the body we shall be pure.

\subsection{Aristotle's View of Mind-Body Interaction}

In his book, De Anima (On the Soul), Aristotle made a great contribution in the understanding of the soul. According to him, the soul is the principle of animal life. He also mentioned that the soul originates the movements. That's why he sees the soul as a substance in the sense of the form of a natural body having life potentially within it. This perception leads to the conclusion that the soul is the actuality of the body. Actuality has two meanings: The possession of knowledge and the exercise of knowledge. Knowledge as possessed, for both sleeping and waking presuppose to actual knowing. Here Aristotle emphasize on the role of the soul in the possession of knowledge and its application. Speaking to the organized body, the soul, said Aristotle, is the first grade of actuality of a natural body having life potentially in it. The soul appears as well as the essential whatness of the body (Aristotle \& McKeon, 1992).

To make his view clear, Aristotle wrote: "The soul is actuality in the sense corresponding to the power of sight and the power in the tool; the body corresponds to what exists in potentiality... so the soul plus the body constitutes the animal". ${ }^{3}$

According to Aristotle the body is like an axe and the soul is its essence. Once the soul disappeared from the body, it would have ceased to be an axe, except in name. Then he compares the relationship between soul and body to the eye and sight. It means without the sight the eye is no longer an eye, except in name (Aristotle \& McKeon, 1992).

From this perspective, one can say that the soul governs over the body and grants him sense and value. The beauty of the body, its glory depend on the greatness of the soul (Aristotle \& McKeon, 1992).

\subsection{Descartes' View}

Substance Dualism is the philosophical position that states such as physical and mental are two kinds of substances. Therefore, there are two kinds of properties. Substance Dualism teaches that the human mind and body are two different substances united. From this perspective, mind is different from the physical brain that is why when the brain ceases to exist the mind continues to exist. This understanding of mind-body was developed by Descartes. The Cartesian view of mind-body relation raises two major problems: ontological and epistemological (Bailey, 2014). For example, Descartes argues that mind and body are two different kinds. From this perspective it appears that mind and body are ontologically different. In her book entitled "Descartes's Dualism", Marleen Rozemond gives quality details about the distinction between mind and body (Rozemond, 1998). She emphasizes on the fact that the real distinction of mind and body consists not in their separability, but in their being different substances. She wrote: "One connection between real distinction and separability, as we have ${ }^{3}$ Aristotle, On Soul, Book II 172-173. 
seen, is that the first entails the second. For Descartes a substance is a thing that exists in its own right, and for this reason it can exist without anything else. So it follows from the idea that mind and body are really distinct, that is, are different substances that they can exist without one another. Nevertheless, it does not follow from these considerations that Descartes infers the separability of mind and body from their being different substances and really distinct." ${ }^{\text {"4 }}$

Descartes held that minds and bodies are substances of distinct kinds. According to him the world is made up of substances. He regards substances as individual things or entities. A material substance is a substance possessing the attribute of extension. A mental substance, in contrast, is a substance possessing the attribute of thought. Then he conceives that bodies are material substances possessing the attribute of extension. But mind possess the attribute of thought. Every substance possess exactly one attribute. No extended substance thinks, and the same way no thinking substance is extended. So minds are distinct from bodies (Descartes, Veitch, \& Hoyt-O’Connor, 2008).

The distinction between mind and body is argued by Descartes in Meditation VI as follows: I have a clear and distinct idea of myself as a thinking, non-extended thing, and a clear and distinct idea of body as an extended and non-thinking thing. Whatever I can conceive clearly and distinctly, God can so create. So, from the above statement, it appears that the mind, a thinking thing, can exist apart from its extended body. And therefore, the mind is a substance distinct from the body, a substance whose essence is thought (Descartes, Thouverez, Luynes, \& Clerselier, 1932).

\section{The Eminence of the Mind over the Body}

\subsection{Philosophical Perspective}

Looking at the events and facts as constituting a system, bring another understanding about how things are related. The main idea of the concepts of supervenience is the interconnectedness of things. In mind-body perspective it appears that mind and body enter into dependency relationships one another. When we speak about interconnectedness we speak about mutual influence between two or more events. The example of Aristotle about the ship and the sailors can make this understandable. Two kind of movement are having at the same moment. The sailors move the ship directly but the sailors in the ship is moved indirectly. This example explains the interconnection between body and soul. The soul moves the body directly and the same way the soul is moved indirectly because the soul is in the moving body. The doctrine of remembrance of Plato can be understood in the same light. Concerning the possible influence of the body over the soul, Plato wrote: "The body keeps us busy in thousand ways because of its need for nurture. Moreover, if certain diseases befall it, they impede our search for truth. It fills us with wants, desires, fears, all sorts of illusions..." Plato is convinced that in the interaction between soul and body, the

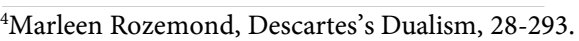


soul can be affected. This understanding is important in our research.

Even though Descartes demonstrates with conviction that mind and body are related in the way that they are closely joined, however we can see the eminence of the mind over the body in their relation. We mean by the eminence of mind over the body that human being is more determined by the mind than the body. It also means that the mind governs over the body. Why do we think so? Here are some reasons

Before Descartes could discover the cogito, he was upset about the false opinions that he previously admitted as true since his childhood. Then to Descartes everything was doubtful as well his own physical body. In the meditation, Descartes is willing to solve the problem of truth which last. Then before getting the certainty, Descartes considers all his knowledge to be false. In the process of doubt, Descartes discovered the first true which is the think; and from the think, his own existence. Although Descartes' reasoning here is best known in the Latin translation cogito, ergo sum which means I think, therefore I am (Descartes, 2012). He wrote: "But there is some deceiver or other, very powerful and very cunning, whoever employs his ingenuity in deceiving me. Then without doubt I exist also if he deceives me, and let him deceive me as much as he will, he can never cause me to be nothing so long as I think that I am something. So that after having reflected well and carefully examined all things, we must come to the definite conclusion that this proposition: I am, I exist, is necessarily true each time that I pronounce it, or that I mentally conceive it" (Descartes, 2012).

The fact that Descartes is strongly convinced that the powerful deceiver and cunning cannot anymore deceive him about his existence is due to the mental conviction. It goes like this, since I am sure in my mind that I am, the deceiver does not have any power on me. When you look at the reasoning carefully we perceive the power of the mind. That's why Descartes could say in meditation II: "But what therefore am I? A thinking thing. What is that? I mean a thing that doubts, that understands, that affirms, that denies, that wishes to do this and does not wish to do that, and also that imagines and perceives by the senses."

Descartes is convinced that even a very powerful and very cunning deceiver cannot deceive him about what he thinks to be. That is really very important to quote. This view is supported by functionalism; which argues that mental states play important roles in our lives. Mental states impact our behavior by the information they carry from the environment. According to the view of functionalism the main function of mental states is their causal role. Aquinas is convinced that the mind governs the body. According to him, a form is loftier to the extent that it is more dominant over corporeal matter. The eminence of the mind over the body appears clearly in his philosophy. Aquinas explained that domination based on the following reasons:

First loftier nature of the mind, and second its power which is called intellect. According to him the farther we go in loftiness, the more we notice the power of ${ }^{5}$ RENÉ DESCARTES Meditations on First Philosophy with Selections from the Objections and Replies, p 20. 
the form. When you consider closely his view there is close relationship between the loftiness of the form and its power. The fact that Aquinas said it openly shows us his conviction about it. Even though mind body are united, integrated, harnessed; they don't have equal influence in their union. One is greater and powerful, and that one is the mind. Once there is difference of nature, equal relationship become almost impossible.

In his book entitled Treatise on Human Nature, Aquinas wrote in Question 76. 1: "It is important to consider, however, that to the extent a form is loftier, to that extent it is more dominant over corporeal matter, less immersed in it, and more surpasses it in its operation or power. For this reason we see that the form of a mixed body has an operation that is not caused by the elemental qualities. And the farther we go in loftiness among forms, the more we find that the power of the form surpasses the elemental matter. the vegetative soul beyond the form of metal, and the sensory soul beyond the vegetative soul. But the human soul is the ultimate in loftiness among forms. Thus its power so surpasses corporeal matter that it has an operation and power that it in no respect shares with corporeal matter. And this power is called the intellect".

\subsection{Eminence of the Mind over the Body from Ideological Perspective}

The decision of the action comes before the action itself. Why do people do what they do? Why do they refuse to be involved in some actions? The answer is simple: the ideology that a man receives from his childhood, believes, education determine his action. The confident that we develop in our mind leads us to take footsteps in actions.

In the history we can notice that all the people who distinguished themselves once upon the time (such as Greek people; German people under Hitler, American people, Japanese and Chinese) had a strong ideological conviction about themselves. Those who think that they were born to win, will never give up until they win. Those who develop the mind of superiority will never tremble when they face challenges. It doesn't matter how tall or big or physically strong you are, if your mind is not strong enough you will lose the battle. The real victory or defeat come from the mind of the winner or the looser. The success and the failure are produced in the mind and lived in reality. Let us consider for instance the reason of Africa being since a developing continent despite its interest in socialism ideology since 1960'. Why socialism could work in China and not in Africa?

Nationalism or Patriotism ideology means being faithful to ones' nation or country. It is the willingness to be devoted, to accept self-sacrifice for the interests of the country. Socialism cannot function without patriotism. The dictatorial regime force people to serve the nation and defend its interests. But in socialism citizens are trained to serve the nation with love and devotion. The dedication of the people can readily eliminate fraud, corruption and unfaithfulness. A patriot sees the state first and then himself after. The culture of patriotism is not 
a new value in African society; it's just a value distorted. When people are proud of their nation and have examples to follow, so officials don't need any extra effort to win the trust of citizens. About patriotism, the first example must be shown by officials and then the others follow. China is a perfect example in that case. Chinese people are proud of their nation and their leaders.

In her book entitled Nationalism and the Mind, Liah Greenfeld wrote: "The products of this cultural process are stored in the environment within which our biological life takes place, but the process itself goes on inside us. In other words, culture exists dynamically, develops, regenerates, transforms only by means of our minds-which makes culture a mental process. Let me reiterate: culture is a symbolic and a mental process" ${ }^{\text {. }}$.

From above statement, Liah conclude that nationalism inhibits the formation and normal functioning of the human mind. We can see how deep and great the role of mental is in the development of people and societies. That's why Liah is convinced that Humanity is not Genetic but rather Symbolic. By defining culture as symbolic and mental as process, it appears to us that the mental governs over the physical.

Rebellions and civilian wars in Africa can be explained by that anomie we talked above. It is unacceptable that someone who loves his nation or who identify himself to his nation, be the one destroying it. In many cases Rebels and loyalist governments armies are all mercenaries, they use citizen to satisfy their personal target. They all serve the population as a shield to get what they really want. The future belongs to those States that have managed to bring their people to act as good nationalist. Freedom in this case is not measured by the impunity, rather to serve with genuine love without external constraint. All these comprehensions are about the mind, they are just displayed in the real life. As we said previously the great nations are those who are ideologically prepared with strong believe.

The mind is strong enough to change the entire destiny of somebody. We don't become a great personality because of the physical weight but because of inner conviction which is the virtue of the mind. From ideological perspective, the mind plays a great role in the conception of standing point. We can even say that the body looks like an envelope without mind. We are what we think to be not as we appear to people. It's unfortunate that many African leaders don't have the ideological stand or conviction. It's important to know that the state of mind is quite imposing in leadership. It is neither fortune nor weight that is important in the criterion of the choice of a leader. It is his state of mind that makes him a leader. Of course the lion is the king of the bush; yet he is not the greatest animal of the forest nor the strongest. The lion has a very particular state of mind. When the hungry lion encounters an animal, he is not intimidated by the size of the animal. He conceived within himself I must eat this animal to survive. In other words, the lion has a state of mind that allows him to desire beyond the ${ }^{6}$ Greenfeld, Liah, Nationalism and the Mind, P-213. 
understanding. The other animals, strongly convinced of the lion's determination, fear him just by seeing him.

Determination is a quality of mind that the leader must have if he does not want to be a leader by name. Never give up before trying repeatedly. For the limits of man are in his mind and not in the physical. The leader must be strong in his mind in order to be able to feed the hopes of his followers. A lazy person can never be the author of a real revolution in terms of work.

Thus we can also say that without conviction man is powerless and vulnerable. Conviction is not in itself the business, however it is the necessary condition to make the business reliable. A man out of conviction is like a light object that moves by the wind in all directions. Such an individual is a real danger to himself and to the society. One can possess knowledge, if conviction is not associated, the knowledge will remain sterile. Instead of producing greater things, it becomes an unsustainable burden. In this case we can say that "mountain has given birth to the mouse". It is the conviction that makes a researcher a scientist or a savant. The scientist who is convinced that with his formula he can make an invention begins to do the research accordingly. Despite the multiple failures, he will pursue his research by the power of conviction until something happens. It is the conviction that gives rise to great minds. It sharpens determination and values skills. Conviction produces the dream and transforms it into reality. It is better to fight at the front with a companion convinced than with thousands of cowards who will not hesitate to give up the battle against the slightest ambush. Conviction is a force, therefore a convinced man is promoted to victory. On the other hand the lack of conviction is a weakness that leads inevitably and surely into defeat.

\subsection{Eminence of the Mind over the Body from Medical Perspective}

In some other areas such as medicine and religion, we see the eminence of the mind over the body. In her book entitled "MIND OVER MEDICINE", Dr. Lissa Rankin explained how through the power of the mind one can heal his body. According to her just by changing how your mind thinks and feels, the body can be impacted. Based on living testimonies she strongly believes that our mind can play a key role in the process of healing even taking care of our own physical health. Dr. Lisa is not only a writer, she is also an experienced physician who is trying to help both patients and healthy people to maintain good health. Quoting from Anne Harrington's, Rankin wrote: “Sometime bodies don't respond the way they should and the only way we can explain such mysteries is through the power of the mind'. From the stories of patients who healed themselves from incurable and terminal illnesses, Rankin developed deep studies about the role of mind in the process of healing. The way that positive mind can heal the body, by the same way the bad state of the mind can make the body sick. That's why Socrates said:

"There is no illness of the body apart from the mind." (Rankin, 2013).

Base on the stories of patients who healed themselves from incurable and ter- 
minal illnesses, Rankin developed deep studies about the role of mind in the process of healing. The way through the mind the body can be healed, by the same way the bad state of the mind can make the body sick. That's why Socrates could said there is no illness of the body apart from the mind. The ancient healing practices in traditional Chinese Medicine recognized the link between the mind and the body. In 1964, psychiatrist George Solomon noticed that people with rheumatoid arthritis got worse when they were depressed. Most of the sickness such as blood pressure, heart problems, Obesity, heart burn, depression, anxiety, asthma, Alzheimer, Diabetes, Gastrointestinal problems, Headaches, and insomnia are the consequences of stress. The stress is the state of the mind being in prison of unsolved questions. If we are strong enough in our mind, and are able to keep the mind relaxing, the body will escape from many sickness that can damage him.

We can say that the more you are positive in your mind, the healthier is the state of your body. Imagine for example a sick person who does not trust the doctor or the nurse treating him. His state will get worse daily and if there is no change, the sick person will die in his sickness. That's why some wise people think that the drugs are hope but healing comes from God. Generally the body desire things that are harmful to it. People suffering from diabetes are tempted to eat food that increased glycaemia. Immature persons exposed themselves to things that are dangerous for their health. An immature person is anybody who is more led by the body that the mind. The statement of Socrates is full of meaning and it helps us to understand the real eminence of the mind over the body. From above statements, it appears clearly that the mind governs over the body and the body subjects to the mind. We can say that the more you are strong in your mind, the healthier is the state of your body. Imagine for example a sick person who does not trust the doctor or the nurse treating him. His state will be worse daily and if there is no change, the sick person will die in his sickness. That's why some wise people think that the drugs are hope but healing comes from God. Generally the body desire things that are harmful to it. People suffering from diabetes are tempted to eat food that increased glycaemia. Immature persons exposed themselves to things that are dangerous for their health. An immature person is anybody who is more led by the body that the mind. The statement of Socrates is full of meaning and it helps us to understand the real eminence of the mind over the body. From above statements, it appears clearly that the mind governs over the body and the body subjects to the mind.

\subsection{Eminence of the Mind over the Body from Biblical Perspectives}

In the bible we can read as follow: "Do not conform any longer to the pattern of this world, but be transformed by the renewing of your mind. Then you will be able to test and approve what God's will is his good, pleasing and perfect willp ${ }^{7}$.

The true change or transformation of one's character starts from the mind.

There is a saying quote as: "habit is a second nature". When a man develops a

${ }^{7}$ Bible study, Romans 12: 2. 
particular habit in the body, it will be difficult for him to leave it. But once he changes his mind, then the body will be under the control. Before going on the cross, Jesus was encouraging his disciples saying that the spirit is willing but the flesh is weak. The body is really weak in the sense that its desires are against the godly pattern. Describing the works of the flesh, there are sexual immorality, impurity, sensuality, Idolatry, sorcery, enmity, strife, jealousy, fit of anger ... Because of this reality the discipline is requested of the body

The body needs to be submitted to a strong psychological understanding of godly pattern. Apostle Paul said: "Therefore I do not run aimlessly; I do not fight like I am beating the air. No, I discipline my body and make it my slave, so that after I have preached to others, I myself will not be disqualified".

The body needs to be disciplined, strike so that man may be able to fulfill the perfect will of the Lord.

In the bible we have a clear mention about the body and the soul of man and what will happen to each of them after the death. "And the dust returns to the ground it comes from, and the spirit returns to God who gave it" (The NIV/Living Parallel Bible: New International Version, Living Bible, 1982).The body and the mind are two different realities. After death, the body returns to the dust and the spirit returns to God. So we see clearly the concept of dualism in this biblical passage with a clear explanation. In terms of eminence of the mind on the body there is no doubt. For the Bible defines the destiny of the spirit which is the upper and the body which returns to the dust. Thus, the reason why the spirit of man returns to God after death seems to mean that our Creator (God) preserves it as a permanent collection of all that touches the individual.

Moreover, because the Spirit of God speaks to the spirit of man, it explains further that the mind is superior to the body even if they have been merged for a time. "The Spirit itself bears witness to our spirit that we are children of God". The body is corruptible while the soul is not. The soul leaves the body, it does not die with the body. In the bible the corruptibility of the body and its inability to inherit the kingdom of heaven is clearly mentioned. The actual body being corruptible, Apostle Paul wrote: "For our dying bodies must be transformed into bodies that will never die; our mortal bodies must be transformed into immortal bodies"

\subsection{Eminence of the Mind over the Body: Biblical Perspectives}

In the bible we can read as follow:"Do not conform any longer to the pattern of this world, but be transformed by the renewing of your mind. Then you will be able to test and approve what God's will is-his good, pleasing and perfect will". ${ }^{10}$ The true change or transformation of one's habit start from the mind. There is a saying quote as: "habit is a second nature". When a man develops a particular habit in the body, it will be difficult for him to leave it. But once he

\footnotetext{
${ }^{8}$ Bible study, 1Corinthians 9: 26-27.

${ }^{9} 1$ Corinthians 15: 53, English Standard Version.

${ }^{10}$ Romans 12: 2, New International Version.
} 
changes his mind, then the body will be under the control of the mindset. Before going on the cross, Jesus was encouraging his disciples saying that the spirit is willing but the flesh is weak. The body is really weak in the sense that its desires are against the godly pattern. Describing the works of the flesh, there are sexual immorality, impurity, sensuality, Idolatry, sorcery, enmity, strife, jealousy, fit of anger ${ }^{11} \ldots$ Because of this reality the discipline of the body is requested.

The body needs to be submitted. Apostle Paul said: "Therefore I do not run aimlessly; I do not fight like I am beating the air. No, I discipline my body and make it my slave, so that after I have preached to others, I myself will not be disqualified". ${ }^{12}$ The body needs to be disciplined, strike so that man may be able to fulfill the perfect will of the Lord.

In the bible we have a clear mention about the body and the spirit of man and what will happen to each of them after the death. "And the dust returns to the ground it comes from, and the spirit returns to God who gave it". ${ }^{13}$ The body and the mind are two different realities. After death, the body returns to the dust and the spirit returns to God. So we see clearly the concept of dualism in this biblical passage with a vivid precision. In terms of eminence of the mind on the body there is no doubt. For the Bible defines the destiny of the spirit which is the upper and the body which returns to the dust. Thus, the reason why the spirit of man returns to God after death seems to mean that our Creator (God) preserves it as a permanent collection of all that touches the individual.

Moreover, because the Spirit of God speaks to the spirit of man, it explains further that the mind is superior to the body even if they have been merged for a time. "The Spirit itself bears witness to our spirit that we are children of God". ${ }^{14}$ The body is corruptible while the soul is not. The soul leaves the body, it does not die with the body.

In the Bible the corruptibility of the body and its inability to inherit the kingdom of heaven is clearly mentioned. The actual body being corruptible, Apostle Paul wrote: "For our dying bodies must be transformed into bodies that will never die; our mortal bodies must be transformed into immortal bodies" ${ }^{15}$

\subsection{From Faith to Miracle Healing}

The faith is defined in the bible as follow "Now faith is confidence in what we hope for and assurance about what we do not see." ${ }^{" 16}$ It appears here that faith is built in the inner being of the believer. It's not measurable by somebody else. Faith is defined as belief with strong conviction; firm belief in something for which there may be no tangible proof; complete trust, confidence. Faith is the opposite of doubt, but both are the fruit of mindset. The miracle can be unders-

\footnotetext{
${ }^{11}$ Galatians 5: 19, Study Bible.

${ }^{12} 1$ Corinthians 9: 26-27, NIV.

${ }^{13}$ Ecclesiastes 12: 7, New International Version.

${ }^{14}$ Romans 8:16, New International Version.

${ }^{15} 1$ Corinthians 15:53, New Living Translation.

${ }^{16}$ Bible study, Hebrews 11: 1.
} 
tood as an extraordinary event manifesting through divine intervention in human affairs. So it appears that miracle is extraordinary which means above ordinary (Group Publishing \& Tyndale House Publishers, 2008).

One day a man came to Jesus with a need of healing. Jesus explained him something very important about faith in the following statement: Then Jesus said “Did I not tell you that if you believe, you will see the glory of God?' (Barker \& Kohlenberger, 1994). The man had to do just one thing: believe that Jesus has power to provide healing. The Mind plays the key role in the process of healing in both side: through miracles or through medicine. A sick person needs to trust the physician who is in charge of his treatment and to trust also the drugs to be taken. Rankin gave many examples in both cases. A woman with Lou Gehrig's disease who went to see the healer John of God and got healing. A paralyzed man made a pilgrimage to the healing waters of Lourdes and left walking. Many other wonders were shared by Dr. Lissa to show the power of the mind over the body.

The miracle walk of Peter on the water is another example to describe the faith. "Shortly before dawn Jesus went out to them, walking on the lake. When the disciples saw him walking on the lake, they were terrified. "It's a ghost," they said, and cried out in fear. But Jesus immediately said to them: "Take courage! It is I. don't be afraid." "Lord, if it's you," Peter replied, "tell me to come to you on the water." "Come," he said. Then Peter got down out of the boat, walked on the water and came toward Jesus. But when he saw the wind, he was afraid and, beginning to sink, cried out, "Lord, save me?" Immediately Jesus reached out his hand and caught him. "You of little faith," he said, "why did you doubt?" (Young Women of Faith Bible: N.I. V., New International Version, 2001).

If Peter could remain focus he would have walked to Jesus. This is exactly how people receive miracle healing. Being able to overcome the doubt is the key that opens the door of miracle and it happens in the mind. The case of the woman healed from her flow of blood is one such event that can help the reader of this article to understand the implication of mind in the realization of miracle. It is quoted in Bible: "Just then a woman who had been subject to bleeding for twelve years came up behind him and touched the edge of his cloak. She said to herself "if I only touch his cloak, I will be healed" ( Young Women of Faith Bible: N.I. V., New International Version, 2001).

The physicians of her time were unable to relieve her suffering. She "spent all she had, yet instead of getting better she grew worse. She was convinced that Jesus was her only hope. She believed and touched the garment of Jesus with the conviction that she will be healed. It happened according to her faith in the action of touching Jesus" garment.

If the soul fails to govern over the body, both shall perish together at the end of days. That's why the bible encourage believers to have boldness before men who can only destroy the body but fear God who has power to destroy body and soul. "Do not be afraid of those who kill the body but cannot kill the soul. Ra- 
ther, be afraid of the One who can destroy both soul and body in hell."17 Because the body is able to cause damage to the soul, it is preferable to allow the suffering of the body for the soul to be saved and rest in eternal life. The fact that the body belongs to the earth as its final destiny. Man should not allowed the body to prevent the soul from reaching its destiny. "If your hand or your foot causes you to fall into sin, cut it off and throw it away. It is better for you to enter life crippled or lame than to have two hands and two feet and be thrown into the eternal fire. And if your eye causes you to fall into sin, gouge it out and throw it away. It is better for you to enter life with one eye than to have two eyes and be thrown into the fire of hell." The imperfection of the physical body does not matter but the most important is to keep one's soul pure, safe and perfect. It is true that the current death does not concern the soul, but at the end of days the sinful soul shall perish. "The soul who sins shall die. The son shall not suffer for the iniquity of the father, nor the father suffer for the iniquity of the son. The righteousness of the righteous shall be upon himself, and the wickedness of the wicked shall be upon himself."18

\section{Conclusion}

Mind-body problem has raised so many philosophical thought and school. Questions such as how mind and body are related? Do mental characteristics supervene on physical or the opposite? Is it possible to distinguish mind from body. These are some common questions in philosophy of mind.

Descartes is convinced that the Soul does not exist in the body in the way that it remains neutral to the bodily sensations. Rather they are related one to another and perfectly united. Descartes uses some word like closely joined or intermingled which describe the degree of intimacy. The example of sailor and ship make the statement of Descartes so clear. The readers of Descartes must consider the following details for vivid understanding of mind body interactions. To emphasize the relationship between the two united substances, Descartes notifies that the pain, hunger, thirst which normally belong to the body are also felt by the soul. The body provides things that are essential to the preservation of the soul such as nutrition, locomotion, respiration. The same way the soul provides attention, perception, judgment, knowledge which are beneficial to the body. In their union, there is a two way provision and a holistic dimension. In his book passions of Soul, Descartes writes: "For a perfect grasp of all this we need to recognize that the soul is really joined to the whole body, and can't properly be said to exist in any one part of the body rather than in others. Why? Because the body is a unity that is in a way indivisible its organs are so arranged that the removal of any one of them makes the whole body defective. And because the nature of the soul won't let it have any relation to extension, or to the dimensions or other properties of the matter the body is made of; all it can be related to is the whole assemblage of the body's organs. You can see this in the inconceivabil${ }^{17}$ Matthew 10: 28; Study Bible.

${ }^{18}$ Ezekiel 18: 20, English Standard Version. 
ity of half a soul or a third of a soul, or of a soul's size. And in the fact that the soul doesn't shrink if we amputate some part of the body, and that if the assemblage of the body's organs is broken up the soul completely separates from the body."

In this article, our focus is to emphasize the eminence of the mind over the body, or the soul over the body. We also recognize that the opposite is possible because the body can also influence the soul in some cases. But due to the fact that mind or soul is superior to body by nature, the mind must govern the body for man to live a balance life.

\section{Conflicts of Interest}

The authors declare no conflicts of interest regarding the publication of this paper.

\section{References}

Aristotle, \& McKeon, R. (1992). Introduction to Aristotle (1992 Modern Library ed.). New York: Modern Library.

Bailey, A. (2014). Philosophy of Mind: The Key Thinkers. London: Bloomsbury Publishing.

Barker, K. L., \& Kohlenberger, J. R. (1994). Zondervan NIV Bible Commentary. Grand Rapids, MI: Zondervan Pub. House.

Bostock, D. (1986). Plato's Phaedo. Oxford: Oxford University Press.

Crivellato, E., \& Ribatti, D. (2007). Soul, Mind, Brain: Greek Philosophy and the Birth of Neuroscience. Brain Research Bulletin, 71, 327-336.

https://doi.org/10.1016/j.brainresbull.2006.09.020

Descartes, R. (2012). Meditations on First Philosophy, in Which the Existence of God and Immortality of the Soul Are Demonstrated.

Descartes, R., Thouverez, É., d’Albert Luynes, L. C., \& Clerselier, C. (1932). Les méditations métaphysiques. Paris: E. Belin.

Descartes, R., Veitch, J., \& Hoyt-O’Connor, P. (2008). Principles of Philosophy. New York: Barnes \& Noble.

Group Publishing, \& Tyndale House Publishers (2008). Live: Holy Bible-New Living Translation (2nd ed.). Carol Stream, IL: Tyndale House Publishers, Inc.

Plato, \& Grube, G. M. A. (2002). Five Dialogues (2nd ed.). Indianapolis, IN: Hackett Pub. Co.

Rankin, L. (2013). Mind over Medicine: Scientific Proof You Can Heal Yourself(1st ed.). Calsbad, CA: Hay House, Inc.

Rozemond, M. (1998). Descartes' Dualism. Cambridge, MA: Harvard University Press.

The NIV/Living Parallel Bible: New International Version, Living Bible (1982). Grand Rapids, MI: Zondervan Bible Publishers.

Young Women of Faith Bible: N.I.V., New International Version (2001). Grand Rapids, MI: Zonderkidz. 